\title{
Pola Asuh Orang Tua terhadap Kemampuan Bersosialisasi pada Siswa Kelas IV di SD Inpres 102 Malanu Kota Sorong
}

\author{
Mursalim $^{1}$, Jusmin $^{2} \&$ Nur Wulandari ${ }^{3}$ \\ Program Studi PGSD, Universitas Pendidikan Muhammadiyah Sorong, Indonesia \\ ${ }^{\bowtie}$ E-mail: mursalim47@gmail.com
}

\begin{abstract}
Abstrak
Tujuan penelitian ini adalah 1). untuk mengetahui bentuk pola asuh yang diterapkan orang tua 2). untuk mendeskripsikan pola asuh orang tua terhadap kemampuan bersosialisasi pada siswa 3). untuk mendeskripsikan upaya guru dalam mengatasi siswa yang kesulitan dalam bersosialisasi. Penelitian ini menggunakan jenis penelitian kualitatif, dengan pendekatan studi kasus. Subyek dalam penelitian terdiri dari 1 orang guru kelas IV, 1 orang kepala sekolah, 2 orang siswa kelas IV, dan 2 orang tua di SD Inpres 102 Malanu Kota Sorong. Teknik pengumpulan data dengan menggunakan observasi, wawancara, dan studi dokumentasi. Teknik keabsahan data menggunakan triangulasi sumber dengan teknik analisis data interaktif. Hasil penelitian menunjukkan bahwa 1). bentuk pola asuh yang diberikan oleh orang tua cenderung menggunakan pola asuh permisif. 2). pola asuh orang tua berdampak terhadap kemampuan bersosialisasi pada siswa. 3). guru sudah berupaya dengan baik dalam menangani siswa yang mengalami kesulitan dalam bersosialisasi.
\end{abstract}

Kata Kunci: Pola asuh; kemampuan bersosialisasi

\begin{abstract}
The purpose of this study is 1). to find out the form of parenting applied by parents 2). to describe parenting parents on the ability to socialize to students 3). to describe the efforts of teachers in dealing with students who have difficulty in socializing. This study uses qualitative research, with a case study approach. Subjects in the study consisted of 1 class IV teacher, 1 school principal, 2 class IV students, and 2 parents at 102 Malanu Inpres SD Sorong City. Data collection techniques using observation, interviews, and study documentation. The data validity technique uses source triangulation with interactive data analysis techniques. The results showed that 1). forms of parenting provided by parents tend to use permissive parenting. 2). parenting style affects the ability to socialize in students. 3). the teacher has tried well in dealing with students who have difficulty in socializing.
\end{abstract}

Keywords: Parenting; Ability to Socialize 


\section{PENDAHULUAN}

Keluarga merupakan lembaga sosial pertama dalam kehidupan anak, tempat anak belajar serta menyatakan diri sebagai makhluk sosial. Orang tua merupakan pendidik pertama dalam kehidupan anak karena pendidikan dari orang tua menjadi dasar perkembangan anak yang nantinya akan menentukan tingkah laku, sikap, moral anak terhadap orang lain. Banyak yang dipelajari anak dalam keluarga terutama hubungannya dengan orang tua, cinta serta kasih sayang yang diberikan oleh orang tua akan anak kembangkan dalam hubungan sosialnya. Ketika anak di dalam lingkungan keluarga merasa disayangi, maka anak akan belajar untuk berbagi kasih sayang dengan temannya. Sebaliknya apabila pengasuhan yang anak terima selalu menyalahkan anak, maka anak pun akan belajar mengembangkan perilaku yang sama ketika anak bermain dengan teman- temannya.

Pola asuh dari orang tua sangatlah erat hubungannya dengan kemampuan bersosialisasi pada anak. Sosialisasi itu sendiri merupakan suatu proses dalam kehidupan seseorang untuk menyesuaikan dirinya menerima kebiasaan, tingkah laku, serta norma yang berlaku dalam kehidupan bermasyarakat. Dengan membiasakan anak melakukan interaksi di dalam keluarga maka anak akan terbiasa berinteraksi dengan orang di luar keluarga sehingga anak mampu menjalin persahabatan dengan teman sebayanya. Maka selain hubungan sosial pada keluarga, anak juga akan menjalin suatu hubungan atau ikatan baru dengan teman sebayanya baik itu di lingkungan di tempat tinggal maupun di lingkungan sekolah sehingga ruang gerak sosialnya semakin luas. Anak yang dikatakan memiliki kemampuan sosial yang baik dapat dilihat melalui cara anak berperilaku dengan orang lain seperti, cara anak dalam bermain dengan teman sebayanya, menghormati orang tua, menghormati guru dan menyayangi teman sebayanya. Peran orang tua sangatlah penting dalam memberikan pemahaman terhadap anak akan pentingnya bersosialisasi, karena anak belum memiliki pengalaman untuk membimbing perkembangannya sendiri kearah kematangan. Banyak anak yang belum memahami pentingnya berinteraksi sosial dengan teman sebayanya terutama di lingkungan sekolah, sehingga anak yang tidak dapat berinteraksi dengan baik di lingkungannya dapat menyebabkan anak dijauhi oleh lingkungan dan sulit mendapatkan teman sebayanya dalam bermain maupun kelompok (Susanti, 2015:247).

Begitu pula dengan temuan yang peneliti dapatkan, bahwa siswa di SD Inpres 102 Malanu Kota Sorong khususnya di kelas IV masih banyak yang mengalami kesulitan dalam bersosialisasi, seperti anak suka mengganggu teman, memiliki egoisme yang tinggi, dan juga anak lebih dominan terhadap temannya. Sehingga anak dibenci bahkan dijauhi oleh teman-temannya. Hal ini pun dibenarkan adanya yang berdasarkan hasil wawancara dengan guru kelas IV di SD Inpres 102 Malanu Kota Sorong, ada beberapa siswa yang masih cenderung pasif, suka mengganggu teman yang lain, dan juga egois. Oleh karena itu semua tidak terlepas dari bagaimana peranan orang tua dalam mendidik dan mengasuh anak, sebab pola pengasuhan yang diberikan orang tua sangat menentukan bagaimana sikap dan perilaku anak kelak. Dari uraian yang telah dijabarkan di atas, maka perlu suatu penelitian tentang Pola Asuh Orang Tua Terhadap Kemampuan Bersosialisasi Siswa Kelas IV di SD Inpres 102 Malanu Kota Sorong.

Tujuan penelitian ini adalah untuk mengetahui bentuk pola asuh yang diterapkan orang tua dan bagaimana pola asuh orang tua terhadap kemampuan bersosialisasi pada siswa serta untuk mengetahui bagaimana upaya guru dalam mengatasi siswa yang kesulitan dalam bersosialisasi. Peneliti berharap penelitian ini dapat bermanfaat bagi ahli pendidikan sebagai acuan dan kajian ilmu pengetahuan tentang peranan orang tua sangatlah penting dalam kemampuan bersosialisasi pada anak, dan diharapkan berguna untuk pembentukan perilaku dan kemampuan sosial anak secara tepat dan berkesinambungan dalam rangka 
meningkatkan kualitas peranan pola asuh orang tua agar mampu menerapkan pola asuh yang sesuai dengan nilai-nilai kebaikan dalam kehidupan sehari-hari.

Berdasarkan tata bahasanya pola asuh terdiri dari kata pola dan asuh. Pola dalam Kamus Besar Bahasa Indonesia berarti model, sistem, cara kerja, bentuk (struktur) yang tetap. Sedangkan kata asuh berarti menjaga (merawat dan mendidik), membimbing (membantu, melatih, dan sebagainya) supaya dapat berdiri sendiri. Nisa (2018:20) pola asuh merupakan berbagai metode atau cara orang tua dalam mengasuh, mendidik dan mengajari anak sesuai tujuan orang tua hingga mencapai tahap kedewasaan. Dalam melakukan upaya mendidik, pola asuh orang tua akan tercermin dari perilaku, sikap, serta interaksi antara orang tua dengan anak dalam kehidupan sehari-hari seperti, bagaimana cara orang tua memberikan dukungan terhadap keberhasilan anak, memberikan hukuman, dan bagaimana orang tua menunjukkan kekuasaannya sebagai orang tua kepada anak. Pola asuh adalah sebuah cara orang tua dalam berinteraksi dengan anaknya dengan tujuan memberikan penjagaan, perawatan, pendidikan, serta memberikan bimbingan dalam intensitas waktu yang cukup konstan dengan maksud mengarahkan anak sesuai dengan tujuan yang diharapkan orang tua (Rachmadtullah, 2017:81).

Pola asuh otoriter orang tua adalah cara pengasuhan yang lebih menekankan pada peraturan dan larangan yang tidak seimbang antara orang tua dan anak, orang tua cenderung memerintah dan anak harus menuruti keinginannya, remaja tidak diberi kesempatan untuk bertanya terlebih dahulu saat mendapat tugas dari orang tuannya dan tidak diberi kesempatan dalam menyelesaikan masalahnya sendiri (Cahyanuari 2018: 20-21). Pola asuh otoriter dapat memberikan dampak negatif pada perkembangan psikologis anak. Karena anak cenderung tidak dapat mengendalikan diri dan emosi bila berinteraksi dengan orang lain, serta anak menjadi tidak kreatif, tidak mandiri, juga tidak percaya diri. Sehingga menyebabkan anak menjadi stres, depresi, dan trauma. Oleh karena itu, penerapan pola asuh otoriter tidak dianjurkan (Rakhmawati, 2015:6).

Pola permisif yaitu pola dimana orang tua tidak mau terlibat dan tidak mau pula pusing mempedulikan kehidupan anaknya. Anak menganggap bahwa aspek-aspek lain dalam kehidupan orang tuanya lebih penting daripada keberadaan dirinya. Walaupun tinggal di bawah atap yang sama, orang tua tidak begitu tahu perkembangan anaknya sehingga menimbulkan dampak buruk terhadap anak. Di antaranya anak akan mempunyai harga diri yang rendah, tidak punya kontrol diri yang baik, kemampuan sosialnya buruk, serta terkadang anak merasa bukan bagian yang penting untuk orang tuanya (Lidyasari 2013:8). Menurut Jannah (2015:5), bentuk pola asuh orang tua yang permisif, tidak dapat menanamkan perilaku moral yang sesuai dengan standar sosial pada anak. Karena orang tua bersifat cenderung pasif dan menuruti semuake inginan anak. Begitupun yang dipaparkan (Padjrin 2016:8), pola asuh permisif atau pemanja biasanya tidak memberikan pengawasan kepada anak. Orang tua memberikan kesempatan pada anaknya untuk melakukan sesuatu, mereka cenderung tidak menegur atau memperingatkan anak apabila anak sedang dalam bahaya, dan sangat sedikit bimbingan yang diberikan oleh mereka. Namun orang tua tipe ini biasanya bersifat hangat, sehingga seringkali disukai oleh anak. Pola asuh permisif dilakukan dengan memberikan kebebasan terhadap anak untuk melakukan apapun sesuka hatinya, sedangkan orang tua kurang peduli terhadap perkembangan anak. Pola asuh semacam ini dapat mengakibatkan anak menjadi egois karena orang tua cenderung memanjakan anak dengan materi. Rachmadtullah (2017:81) pola asuh demokratis merupakan pola asuh yang memprioritaskan kepentingan anak, namun orang tua juga masih tetap mengendalikan dan mengontrol anak. Orang tua tipe ini bersikap hangat, dan memposisikan diri seperti teman untuk anak, 
realistis terhadap kemampuan anak, menerima apa adanya anak dan tidak berharap yang berlebihan yang melampaui kemampuan anak serta memberikan kebebasan pada anak untuk memilih dan melakukan suatu tindakan. Selalu mendorong anak untuk membicarakan apa yang ia inginkan, serta orang tua selalu memberikan dorongan dan bimbingan, menunjukan mana yang baik dan mana yang buruk. Pola asuh demokratis ini mendorong anak menjadi mandiri, dapat mengatasi masalahnya, tidak tertekan, berperilaku baik terhadap lingkungan, dan mampu berprestasi dengan baik. Pola pengasuhan ini dianjurkan bagi orang tua (Rakhmawati, 2015: 6-7).

Kemampuan bersosialisasi merupakan suatu kemampuan untuk menjalin hubungan dengan dua atau lebih individu ditandai dari proses yang membentuk individu untuk belajar menyesuaikan diri, bagaimana cara hidup dan berfikir serta berfungsi dalam kelompoknya (Wahyuni 2016:4). Sosialisasi merupakan suatu proses dalam pengetahuan,memperoleh mengembangkan kemampuan sosial, kebiasaan sosial, kepribadian serta pembentukan standar individu tentang keterampilan untuk adalah suatu kemampuan untuk menjalin hubungan dengan dua atau lebih individu yang ditandai dengan kemampuan beradaptasi (Nora 2015:384-385). Proses sosialisasi pada dasarnya tidak selalu berjalan lancar sesuai dengan rencana dan kadangkala juga mengalami berbagai kesulitan. Adapun menurut Bungin (2013) dalam (Lestari 2018), ciri-ciri anak mengalami kesulitan dalam proses sosialisasi antara lain:

1. Anak menjadi acuh tak acuh, tidak butuh orang lain, dan tidak dapat menerima persahabatan. Hal ini diakibatkan sejak kecil mengalami kemarahan, rasa tidak percaya dan gangguan emosi negatif lainnya. Ketika dewasa ia akan menolak dukungan, simpati, cinta dan respons positif lainnya dari orang di sekitarnya. Ia kelihatan mandiri, tetapi tidak hangat dan tidak disenangi oleh orang lain.

2. Berperilaku agresif, yaitu adalah anak selalu ingin menyakiti orang baik secara verbal maupun fisik. Anak merasa bahwa tindakannya tersebut adalah benar dan wajar karena ia sendiri diperlakukan seperti itu.

3. Menjadi minder, yakni anak merasa dirinya tidak berharga dan berguna, terutama oleh orangtuanya. Rasa minder akan berdampak negatif bagi perkembangan jiwa anak, sehingga ia menjadi anak yang menarik diri dari pergaulan.

4. Ketidakstabilan emosional yaitu anak menjadi tidak toleran atau tidak tahan terhadap stres, mudah tersinggung, mudah marah, dan sifat yang tidak dapat dirediksi oleh orang lain.

5. Kesulitan Komunikasi yang merupakan proses penyampaian pikiran atau perasaan oleh seseorang (komunikator) kepada orang lain (komunikan). Ada kesulitan komunikasi, bila anak tidak mengerti apa yang diharapkan daripadanya, atau tak tahu apa yang diinginkan oleh orang lain atau tuntutan kebudayaan tentang kelakuannya.

\section{METODE PENELITIAN}

Jenis penelitian yang digunakan dalam penelitian ini adalah jenis penelitian kualitatif dengan pendekatan studi kasus. Penelitian kualitatif dapat diartikan sebagai jenis penelitian yang berlandaskan pada filsafat postpositivisme, digunakan untuk meneliti pada kondisi obyek yang alamiah, (sebagai lawannya adalah eksperimen) dimana peneliti sebagai instrumen kunci, teknik pengumpulan data dilakukan secara triangulasi (gabungan), analisis data bersifat induktif/kualitatif, dan hasil penelitian kualitatif lebih menekankan makna dari pada generalisasi (Sugiyono, 2016:13-14). Dalam penelitian ini peneliti menggunakan pendekatan studi kasus, yang dimana studi kasus merupakan suatu inquiri empiris yang menyelidiki fenomena dalam konteks kehidupan nyata, bilamana batas-batas antar fenomena dan konteks tak tampak dengan tegas dan dimana multi sumber bukti dimanfaatkan sebagai suatu inquiri studi kasus tidak harus dilakukan dalam 
waktu yang lama dan tidak pula harus tergantung pada data obervasi partisipan (Yin, 2008). Keterangan berupa kata-kata atau cerita langsung dari informan dijadikan sebagai data utama (data primer), sedangkan tulisan atau data dari berbagai dokumen dijadikan sebagai data pelengkap (data sekunder).

Dalam penelitian kualitatif ini peneliti bertindak sebagai instrumen utama yang turun ke lapangan serta berusaha sendiri mengumpulkan informasi baik melalui observasi maupun wawancara serta studi dokumentasi. Observasi yang dilakukan bersifat nonpartisipan yang dimana peneliti sebagai pengamat independen dan tidak terlibat secara langsung. Kemudian wawancara dilakukan bersifat terbuka dan tidak terstruktur, sehingga responden lebih leluasa dalam memberikan informasi, serta penelitipun dapat lebih mudah menggali dan mendapatkan informasi yang akurat berkaitan dengan perrmasalahan yang diteliti. Untuk memudahkan pengumpulan data, peneliti menggunakan alat bantu berupa catatan lapangan, tape recorder, kamera foto dan pedoman wawancara.

Untuk memeriksa validitas data dalam penelitian ini peneliti menggunakan teknik triangulasi sumber. Sugiyono (2016:328), triangulasi sumber berarti untuk mendapatkan data dari sumber yang berbeda dengan teknik yang sama. Peneliti menggunakan teknik ini agar peneliti dapat membandingkan hasil wawancara yang diperoleh dari masing-masing sumber atau informan, serta untuk mengecek kebenaran informasi yang didapatkan.

Analisis data kualitatif bisa saja melibatkan proses pengumpulan data, interprestasi, dan pelaporan serentak dan bersama hasil secara -sama (John W. Creswell 2010). Creswell (2010) terdapat beberapa langkah dalam mengalisis data sebagaimana berikut ini:

1. Mengolah data dan mempersiapkan data untuk dianalisis. Langkah ini melibatkan transkip wawancara, menscaning materi, mengecek data lapangan atau memilah-milah dan menyusun data tersebut ke dalam jenisjenis yang berbeda tergantung sumber informasi.

2. Membaca keseluruhan data. Dalam tahap ini, menulis catatan-catatan khusus atau gagasan-gagasan umum tentang data yang diperoleh.

3. Menganalisis lebih detail dengan mengkoding data. Coding merupakan proses mengolah materi atau informasi menjadi segmen-segmen tulisan sebelum memaknainya.

4. Menerapkan proses coding untuk mendeskripsikan setting, orang-orang, kategori, dan tema-tema yang akan di analisis. Deskripsi ini melibatkan usaha penyampaian informasi secara detail mengenai orang-orang, lokasi- lokasi, atau peristiwa-peristiwa dalam setting tertentu.

5. Menunjukkan bagaimana deskripsi dan tema-tema ini akan disajikan kembali dalam narasi atau laporan kualitatif.

6. Menginterpretasi atau memaknai data yang berasal dari perbandingan antara hasil penelitian dengan informasi yang berasal dari teori-teori. Dalam hal ini, peneliti menegaskan apakah hasil penelitiannya membenarkan atau justru menyangkal dari informasi sebelumnya.

\section{HASIL DAN PEMBAHASAN}

Pola asuh merupakan cara orang tua dalam mendidik, membimbing serta memberikan kasih sayang dengan maksud mengarahkan anak yang perilaku sikap akan tercemin dari pola asuh yang diberikan orang tua. Berdasarkan hasil penelitian, menunjukkan bahwa pola asuh yang diterapkan orang tua siswa kelas IV di SD Inpres 102 Malanu Kota Sorong ini cenderung menggunakan pola asuh permisif. Pola asuh ini ditandai dengan adanya sikap orang tua yang memberikan kesempatan yang seluas-luasnya kepada anak untuk menentukan tingkah laku yang dianggap benar oleh anak tanpa adanya kendali dari orang tua. Hal ini diperkuat hasil wawancara dengan RK selaku orang tua siswa mengatakan bahwa: "Saya tidak pernah 
membantu anak dalam mengerjakan tugasnya, saya memberikan tanggung jawab sepenuhnya pada anak saya untuk mengerjakan tugasnya sendiri, saya sebagai orang tua hanya mengingatkan anak." (wawancara tanggal 03 September 2019). Dari pemaparan di atas, dapat diketahui bahwa orang tua memberikan kebebasan kepada anak untuk berbuat sekehendak hatinya. Hal tersebut juga diperkuat dari hasil wawancara dengan anaknya yaitu EP siswa kelas IV menyatakan bahwa: "Orang tua saya tidak pernah menyuruh saya untuk belajar, terserah saya mau belajar atau tidak." (wawancara tanggal 03 september 2019).

Begitu pun dengan HN selaku siswa kelas IV menyatakan bahwa, orang tua tidak membantu jika ada kesulitan dalam mengerjakan PR. (wawancara 03 September 2019). Namun berbeda halnya dengan penuturan dari EN selaku orang tua $\mathrm{HN}$ mengatakan bahwa: "Iya, terkadang saya membantu kadang juga dia sama temantemannya mengerjakan tugasnya." (wawancara 03 September 2019). Dalam hal menerapkan aturan dan memberi hukuman, orang tua dalam mendidik anak tidak memberikan aturan-aturan serta hukuman terhadap anak. Hal ini diperkuat dengan hasil wawancara dengan RK selaku orang tua dari EP mengatakan: "Tidak ada hukuman yang saya terapkan, apabila anak

melakukan kesalahan saya hanya memarahinya saja." (wawancara 05 september 2019). Pola asuh ini merupakan pengasuhan yang dimana orang tua memberikan kebebasan penuh kepada anak, dan apabila kebebasan tersebut dapat digunakan secara bertanggung jawab, makan akan menjadikan anak sebagai individu yang mandiri, inisiatif, dan juga kreatif. Namun apabila kebebasan itu digunakan secara tidak terkontrol maka akan berdampak pada perkembangan anak dan menjadikan anak kurang disiplin, cenderung agresif, juga egois dan berharap semua keinginannya harus dituruti. Agar anak dapat berkembang dengan baik, maka diharapkan orang tua dapat memahami dan memilih bentuk pola asuh yang tepat dan menyesuaikan aturan yang diterapkan dengan usia anak, karena dengan pola asuh yang tepat dapat menentukan sikap dan perilaku anak di masa depan.

Pola asuh merupakan sebuah cara yang digunakan oleh orang tua untuk berinteraksi dengan anaknya, yang bertujuan memberikan kasih sayang, perawatan, serta bimbingan terhadap anak. Orang tua harus bisa memilih pola asuh yang tepat dan sesuai dengan perkembangan serta karakter anak, sebab pola asuh yang diterapkan orang tua akan berdampak pada perkembangan dan kemampuan anak lebih khususnya kemampuan anak dalam bersosialisasi. Hal ini didasarkan bahwa lingkungan terkecil sosialisasi seorang anak berada dalam lingkup keluarga, dimana orang tua mengambil peranan penting dalam mendidik dan mengarahkan anaknya agar berkembang sesuai dengan tahap perkembangannya. Sebagaimana yang diungkapkan oleh MS selaku wali kelas IV mengatakan: "Mereka berteman baik-baik saja, tidak ada pengecualian antara satu dengan yang lain, hanya saja siswa yang berangkat dari keluarga yang brokenhome biasa tingkahnya suka iseng, suka menggangu temannya, tapi itu dia anggap hal yang biasa karena sikapnya tidak terkontrol dari rumah akhirnya terbawa sampai di sekolah." (wawancara tanggal 05 September 2019). Adapun hasil wawancara dengan EP siswa kelas IV mengatakan bahwa: "Saya pernah berkelahi dengan teman, karena dia mengganggu saya." (wawancara tanggal 03 september 2019). Berdasarkan hasil penelitian dapat diketahui bahwa pola asuh orang tua memberikan dampak yang cukup serius terhadap kemampuan bersosialisasi pada anak. Diketahui dalam penelitian ini bahwa pola asuh yang diberikan menggunakan cara yang permisif. Dimana pola asuh ini orang tua bersifat longgar atau memberikan kebebasan sepenuhnya terhadap anak, sehingga menjadikan anak tidak dapat mengendalikan perilakunya, anak cenderung agresif dan suka mendominasi dari temantemannya serta selalu mengambil sikap ingin menang dan benar. Dengan sikap anak yang 
seperti itu maka anak akan di jauhi oleh teman-temannya. Senada dengan temuan penelitian oleh Baumrind bahwa anak dari orang tua yang berpola asuh permisif, hanya ada sedikit batasan, peraturan dan konsekuensi yang serius. Sehingga anak mudah mengalami kesulitan dalam pengendalian diri, dan menunjukkan sikap egosentris yang dapat mengganggu perkembangan dan hubungan anak dengan teman sebayanya. Maka diharapkan orang tua dapat selektif dalam memilih pola asuh untuk anak, sebab pola pengasuhan yang di berikan orang tua akan berdampak pada kemampuan sosialisasi anak, karena anak hidup dalam keluarga yang selalu mendukungnya dalam cinta kasih sehingga dengan pola pengasuhan yang tepat dan interaksi keluarga yang harmonis maka anak dapat tumbuh dan berkembang secara optimal.

Di lingkungan sekolah guru merupakan orang tua kedua bagi siswa, sehingga pola asuh yang diberikan oleh orang tua maupun guru di sekolah erat hubungannya pada kemampuan sosial anak baik di lingkungan sekolah maupun masyarakat. Berdasarkan hasil wawancara dengan YS selaku kepala sekolah mengatakan bahwa: "Setiap hari pada pukul 07.00 WIT sebelum pelajaran di mulai, kami mengumpulkan anak-anak di lapangan, untuk mengikuti apel pagi dan memberikan nasehat serta arahan kepada siswa. Selain itu kami juga memberikan motivasi terhadap siswa melalui slogan-slogan yang kami tempel di dinding sekolah. (wawancara tanggal 12 september 2019).

Adapun hasil wawancara dengan MS selaku guru wali kelas IV mengatakan bahwa pola asuh yang diberikan disekolah yaitu: "Dalam memberikan pola asuh untuk anak di sekolah saya mencari tau dulu bagaimana latar belakang keluarganya kemudian karakter anak tersebut. Apabila ada kelainan atau hal-hal yang menyimpang, kemudian anaknya saya dekati dan berikan arahan, kemudian memberikan surat panggilan untuk orang tua atau walinya untuk menelusuri mungkin ada masalah dengan keluarganya sehingga menimbulkan sikapnya seperti itu." (wawancara tanggal 05 september 2019). "Mereka berteman baikbaik saja, tidak ada pengecualian antara satu dengan yang lain, hanya saja siswa yang berangkat dari keluarga brokenhome biasa tingkahnya kayak suka iseng, suka menggangu temannya, tapi itu dia anggap hal yang biasa karena sikapnya tidak terkontrol dari rumah akhirnya terbawa sampai di sekolah." (wawancara tanggal 05 september 2019).

Hal serupa yang dipaparkan YS selaku kepala sekolah mengatakan bahwa: "Hubungan antara siswa terkadang mereka bermasalah, kami selaku orang tua mereka di sekolah kami rangkul mereka untuk berbicara memberikan nasehat dan pengertian, bahwa kita ini semua bersaudara dan harus saling menyanyangi antara satu dengan yang lain." (wawancara tanggal 12 september 2019).

Maka dalam hal ini upaya yang dilakukan oleh guru dalam mengatasi anak yang mengalami kesulitan berdasarkan hasil wawancara dengan guru kelas adalah: "Pada anak yang pasif, saya mengatur tempat duduknya dengan siswa yang aktif, kemudian saya sampaikan kepada temannya untuk sering mengajak ia berkomunikasi. Misalnya apabila saya memberikan tugas saya menghimbau pada siswa untuk saling membantu apabila ada teman yang mengalami kesulitan, maka dengan begitu siswa yang tadinya pasif ia sudah mulai mampu untuk berkomunikasi dengan siswa yang lain. Kalau yang agresif pun begitu saya mengatur tempat duduknya, namun siswa yang agresif saya tempatkan tempat duduknya paling depan dekat dengan saya sehingga mudah saya kontrol pada saat proses pembelajaran." (wawancara tanggal 05 september 2019). Adapun upaya lain yang guru lakukan berdasarkan hasil wawancara dengan MS selaku wali kelas IV mengatakan bahwa: "Anak usia sekolah dasar mereka paling senang apabila di berikan pujian maka apapun hasil pekerjaannya walau belum memuaskan atau belum sesuai dengan apa yang di harapkan dalam hal ini saya selaku 
guru senantiasa memberikan anak pujian serta motivasi sehingga ia akan merasa senang, dan percaya diri."(wawancara tanggal 05 september 2019). Berdasarkan hasil penelitian bahwa guru di SD Inpres 102 Malanu Kota Sorong khususnya pada kelas IV, guru sudah melakukan perannya dengan baik dalam menangani siswa yang mengalami kesulitan bersosialisasi dengan temannya. Ketika siswa yang mengalami kesulitan guru membantu siswa dan senantiasa memberikan nasehat serta arahan tentang arti pentingnya bersosialisasi seperti harus berkomunikasi dengan baik, berbicara sopan, dan saling menghargai satu sama lain. Namun adapun kendala yang dihadapi oleh guru dalam memberikan pengasuhan di sekolah ialah adanya sikap acuh tak acuh dari orang tua siswa. kebanyakan orang tua hanya melepas anak di sekolah tanpa diberikan bimbingan di rumah. Apabila orang tua tidak dapat bekerja sama dengan pihak sekolah maka akan sulit dalam memberikan pengertian terhadap anak. Maka diharapkan kepada orang tua agar selalu dapat berkomunikasi dan bekerja sama dengan pihak sekolah khususnya guru wali kelas untuk dapat mengetahui perkembangan anak.

\section{KESIMPULAN}

Berdasarkan uraian dari hasil penelitian yang diuraikan pada bab IV tentang pola asuh orang tua terhadap kemampuan bersosialisasi siswa maka dalam penelitian ini, dapat ditarik kesimpulan sebagai berikut:

1. Bentuk pola asuh yang diberikan oleh orang tua cenderung menggunakan pola asuh permisif yang dimana pola asuh ini orang tua cenderung pasif, dan memberikan kebebasan penuh terhadap anak.

2. Pola asuh permisif yang diberikan orang tua sangatlah berdampak terhadap kemampuan bersosialisasi pada siswa. Dimana anak cenderung agresif dan juga suka mengganggu teman sehingga anak tidak dapat bersosialisasi dengan baik. Maka diharapkan orang tua sebagai orang yang paling mengerti keadaan anak, tetap memberikan dukungan kepada anak khususnya dalam hal kemampuan bersosialisasi yang nantinya akan sangat berguna untuk masa depan dan lingkungannya, sehingga diharapkan semua anak dapat mempunyaikemampuan bersosialisasi yang baik dan yang sesuai dengan norma yang berlaku dalam kehidupan bermasyarakat.

3. Guru sangatlah berperan penting dalam membimbing dan mendidik anak di sekolah maka dalam hal ini guru sudah berupaya dengan baik dalam menangani siswa yang mengalami kesulitan dalam proses belajar mengajar maupun dalam bersosialisasi dengan teman sebayanya.

\section{DAFTAR RUJUKAN}

Aida, Nurul, and Rr. Amanda Pasca Rini. 2015. "Penerapan Metode Bermain Peran untuk Meningkatkan Kemampuan Bersosialisasi Pada Pendidikan Anak Usia Dini." Jurnal Psikologi Indonesia 4(01): 87-99.

Cahyanuari, Lolita Dwi. 2018. "Hubungan Antara Pola Asuh Otoriter Orangtua Dengan Perilaku Agresif Pada Remaja."

Jannah, Husnatul. 2015. "Bentuk Pola Asuh Orang Tua Dalam Menanamkan Perilaku Moral Pada Anak Usia Di Kecamatan Ampek Angkek." Jurnal Penelitian 1: 257-58.

John W. Creswell. 2010. Pustaka Pelajar Metode Penelitian. I. Yogyakarta.

Kordi, Abdorreza. 2010. "Pengaruh Sikap Dan Pola Asuh Orang Tua Terhadap Prestasi Siswa." jurnal internasional studi psikologi 2(2): 217-22.

Lestari, Diah Ayu. 2018. "Peran Guru Dalam Mengatasi Kesulitan Bersosialisasi Siswa Di Min Sei Agul Kecamatan Medan Denai Tahun Ajaran 2017/2018."

Lestiawati, I Made. 2013. "Pengaruh Pola Asuh Orang Tua Terhadap Kemampuan Sosial Anak Usia 6-7 Tahun." Jurnal Penelitian 8(2): 11119. 
Lidyasari, Aprilia Tina. 2013. "Pola Asuh Otoritatif Sebagai Sarana Pembentukan Karakter Anak Dalam Setting Keluarga." jurnal pendidikan.

Nisa, Rofiatun. 2018. "Pengaruh Pola Asuh Orang Tua Dan Interaksi Sosial Terhadap Hasil Belajar Mata Pelajaran Matematika Siswa Kelas IV Di Madrasah Ibtidaiyah SeKecamatan Lowokwaru Kota Malang." Universitas Islam Negeri Maulana Malik Ibrahim Malang.

Nora, Maya Oktia. 2015. "Pengaruh Kelekatan Dan Harga Diri TerhadapKemampuan Bersosialisasi Anak." Jurnal Pendidikan 9: 379-88.

Padjrin. 2016. "Pola Asuh Anak Dalam Perspektif Pendidikan Islam." Jurnal Intelektualita 5(1): 1-14. http://jurnal.radenfatah.ac.id/index.ph p/intelektualita/article/view/72 0.

Rachmadtullah, Reza dan Winda Wirasti Aguswara. 2017. "Pola Asuh Orang Tua Terhadap Kecerdasan Sosial Ssiwa Kelas Awal Sekolah Dasar." Jurnal Ilmu Pendidikan 2 (02).

https://ejurnal.esaunggul.ac.id/ind ex.php/EDU/article/view/1829/16 43 (April 26, 2019).

Rakhmawati, Istina. 2015. "Peran Keluarga Dalam Pengasuhan Anak." Jurnal Penelitian 6(1): 1-18.

Sari, Ernani Yunita. 2015. "Pengaruh Pola Asuh Orang Tua Terhadap Prestasi Belajar Ips Siswa Kelas V Sd SeGugus III Seyegan Sleman Tahun Ajaran $2014 \quad$ / 2015.” Jurnal Penelitian (2).

Sarwar, Samiullah. 2016. "Pengaruh Pola Asuh Orang Tua Pada Perilaku Anak." jurnal pendidikan 3 (December): 222-49.

Siti Anisah, Ani. 2011. "Pola Asuh OrangTua Dan Implikasi Terhadap Pembentukan Karakter
Anak." Jurnal Pendidikan

Universitas Garut 05(01): 70-84. https://journal.uniga.ac.id/index.p hp/JP/article/viewFile/43/43.

Sri Puji Lestari, Dwi Pepri Rahmawati. 2017. "Pola Asuh Orang Tua Versus Kemampuan Sosialisasi Anak." jurnal keperawatan 9(2): 65-69.

Sugiyono, Prof. Dr. 2016. Metode Penelitian Kombinasi (Mixed Methods). ed. M.T. Sutopo. Bandung: ALFABETA, cv.

Suteja, Jaja. 2017. "Dampak Pola Asuh Orang Tua Terhadap

Perkembangan Sosial-Emosional Anak." jurnal pendidikan anak 3(Pola Asuh, Perkembangan, SosialEmisonal A.): 1-14.

Trinataliswati, Kasiata, Lucia Retnowati. 2010. "Perbedaan Kemampuan Bersosialisasi Pada Anak Prasekolah Dengan Riwayat PAUD Dan Tanpa Riwayat PAUD Di Desa Sumber Porong Lawang." Jurnal Keperawatan 1: 199-206.

Widowati, S. Nurcahyani Desy. 2013. "Hubungan Antara Pola Asuh Tua, Motivasi Belajar, Kedewasaan Dan Kedisiplinan Siswa Dengan Prestasi Belajar Sosiologi Siswa XI SMA Negeri 1 Sidoharjo Wonogiri." Jurnal Penelitian: 1-25.

Zazimah. 2015. "Pengaruh Pola Asuh Otoriter Terhadap

Tingkat Agresivitas Anak Usia 4-5 Tahun Di Ra Insan Harapan, Kecamatan Pandak, KabupatenBantul." https://lib.unnes.ac.id/22612/1/16 01411035-s.pdf (May 4, 2019).

Zazimah. 2015. "Pengaruh Pola Asuh Otoriter TerhadapTingkat Agresivitas Anak Usia 4-5 Tahun Di Ra Insan Harapan, Kecamatan Pandak, KabupatenBantul." https://lib.unnes.ac.id/22612/1/16 